\title{
Selection of bull dams for production and functional traits in an open nucleus herd
}

\author{
H. Hansen Axelsson, ${ }^{\star 1}$ K. Johansson,† S. Eriksson, ${ }^{\star}$ K.-J. Petersson, ${ }^{*}$ L. Rydhmer, ${ }^{\star}$ and J. Philipsson* \\ *Swedish University of Agricultural Sciences, Department of Animal Breeding and Genetics, Box 7023, SE-750 07 Uppsala, Sweden \\ †Swedish Dairy Association, Box 7023, SE-750 07 Uppsala, Sweden
}

\begin{abstract}
The aim of this study was to compare different scenarios for bull dam selection in a nucleus herd. A deterministic simulation study using selection index methodology was undertaken. In the scenarios studied, differing amounts of information on functional traits were available when bull dams were selected, and the resulting genetic responses in these traits were compared. Field-recorded fertility traits used in the scenarios were available as progeny test results of artificial insemination bulls: these included pregnant at first insemination (PFI), interval between calving and first insemination (CFI), and cases of reproductive disorders (RD). Similarly, field-recorded cases of clinical mastitis (CM), lactation somatic cell score (LSCS), and protein yield (PY) were included for pedigree selection. In the scenarios, heat intensity score and progesterone levels were treated as new indicator traits of fertility recorded in the nucleus herd. Traits CFI and LSCS were assumed to be better recorded with higher heritability in the nucleus herd than in ordinary herds. Economic weights currently used in Nordic Cattle Genetic Evaluation (NAV) were adapted and used in the scenarios. The results showed that these weights, if used in multiple trait genetic evaluation, would lead to undesirable genetic changes in functional traits for the bull dam selection path in a nucleus environment. More frequent recording of additional traits failed to improve selection for functional traits, as did more frequent recording of ordinary traits. Restriction index methodology was used to derive the bull dam total weights that gave no unfavorable response (i.e., zero genetic change) in traits PFI, CFI, and CM. When summarized over lactations, the new bull dam total weights, when additional records from nucleus were used, had to be 12 to 23 times higher for fertility, and 3 times higher for mastitis, than the presently used NAV weights, if these traits were to remain unchanged through the bull dam selection path.
\end{abstract}

Received May 26, 2010.

Accepted February 1, 2011

${ }^{1}$ Corresponding author: Helen.Hansen@hgen.slu.se
Thus, nucleus herd selection of bull dams is questionable for low heritability traits that are already recorded in the field.

Key words: selection index, bull dam, functional trait, economic weight

\section{INTRODUCTION}

When modern dairy cattle breeding started, the focus was on improving milk production and conformation. Traits that are unfavorably correlated with milk production, such as udder health and fertility, displayed undesirable genetic trends and had to be given special consideration (Philipsson et al., 1994; Pösö and Mäntysaari, 1996; Roxström, 2001).

Multiple ovulation and embryo transfer (MOET) nucleus breeding schemes have been shown to rapidly improve genetic gain in traits with high heritabilities such as milk production and conformation traits (Bovenhuis et al., 1989; Strandén et al., 2001). Nucleus herds also provide a suitable environment in which to test and select potential bull dams, as the cows are kept under the same environmental conditions and, thus, are tested on equal bases. This eliminates the preferential treatment of bull dams and the bias in their EBVs that otherwise occurs (Uimari and Mäntysaari, 1995; Zwald and Weigel, 2002).

Strandén et al. (2001) simulated MOET schemes and compared these with a conventional AI scheme. The best results were achieved in a hybrid MOET scheme with progeny of nucleus-born bulls tested in an AI population. The genetic response in milk and protein yield in hybrid schemes was 40 to $78 \%$ higher than it was in the regular AI scheme. This result was thought to be due to more successful cow selection. Increased utilization of bulls born out of bull dams tested and selected in a nucleus herd might therefore lead to rapid genetic progress in highly heritable traits.

Several other theoretical studies with closed or open nucleus herds have been reported. Early work included only one trait (milk production) in the breeding objective (Juga and Mäki-Tanila, 1987; Meuwissen, 1989). Meuwissen and Woolliams (1993) used multi-trait se- 
lection to predict the responses of selection for milk production and secondary traits that had the same heritability as milk yield. Teepker and Smith (1990) included milk production and another trait with different values of heritability, correlation, and relative economic weight in their breeding objective. They calculated the theoretical rates of genetic response in a closed nucleus breeding scheme and compared the results with those obtained from conventional AI schemes. Their general conclusion was that the genetic response for an aggregate breeding objective in a nucleus scheme exceeded the progress of the AI scheme. Teepker and Smith (1990) gained a considerably better response by testing additional parental half-sib groups from a simulated MOET scheme. The highest level of response was gained in a MOET + scheme that represented an open nucleus scheme; that is, the semen from selected nucleus-born bulls was used in herds outside the nucleus. The overall response in the breeding objective that included, besides a production trait, a second trait with low heritability was highest in the MOET+ scheme. However, to achieve a higher overall response in such a breeding scheme than that secured in progeny testing schemes, $60 \%$ or more of the economic weight had to be placed on the trait with low heritability.

If bull dams are selected from among the cows in nucleus herds, it is vital to ask how selection for low heritability traits in a nucleus herd can be improved. Only a limited number of records on cows' own performance are available. The selection of bull dams must occur early if it is to be ahead of the progress in the AI population. At the nucleus herd Viken, located in southwest Sweden, Holstein and Nordic Red cows are performance-tested. Generally, the bull dam candidates have records only from the first lactation and, on production, from the first $60 \mathrm{~d}$ of the second lactation. The information available on the nucleus limits the accuracy of selection, and because of this, selection for traits with low heritabilities is difficult (Bovenhuis et al., 1989). Therefore, it is important to find strategies that fully utilize the potential provided by the nucleus environment and, by recording traits of interest, provide early information. For example, SCC could be recorded more frequently, and new indicator traits could be introduced for fertility and health. Some studies propose progesterone (Petersson, 2007) and heat intensity score (Roxström, 2001) as indicator traits for fertility; electrical conductivity in milk (Norberg, 2004) may be useful as an additional measure of udder health.

The aim of the present simulation study was to estimate genetic response and accuracy in functional traits with low heritability when bull dams are selected from an open nucleus herd. New bull dam total weights needed in a multiple trait genetic evaluation to prevent an unfavorable response in functional traits were also derived. Differing amounts of information on routinely recorded functional traits and new indicator traits for fertility and udder health were included in the study.

\section{MATERIALS AND METHODS}

\section{Structure of Scenarios, Breeding Objectives, and Selection Index Definitions}

The design of the scenarios used in this study was based on the way of selecting bull dams in the Nordic open nucleus herd Viken. The number of cows kept in Viken herd was approximately 320 . The principle of the nucleus herd was to recruit annually about 100 heifers to the nucleus scheme. Most (approximately 80\%) were recruited externally from conventional herds, with the remainder (approximately 20\%) being recruited internally (H. Stålhammar, Viking Genetics, Skara, Sweden, personal communication). In the tested scenarios, all heifers recruited to the nucleus herd were presumed to be sired by proven bulls that had been progeny-tested with 100 effective daughters for a range of production and functional traits. The pedigree index of the heifers also included maternal grandsire information based on a progeny group size of 100 daughters. It was assumed that the heifers were unrelated.

The study focused on the individual cow, the potential bull dam. The information sources used were the sire's progeny group $(s)$, the maternal grand sire's progeny group $(\boldsymbol{m s})$ (with both of these consisting of first- and second-lactation records for production, fertility, and udder health from 100 daughters), and own records of the individual bull dam (o), either as a heifer or a cow in a nucleus herd. When all the information for a bull dam was available, then

$$
\begin{gathered}
\mathbf{x}_{P}, \mathbf{x}_{F} \text {, and } \mathbf{x}_{U}=\left[\begin{array}{c}
\mathbf{x}_{s} \\
\mathbf{x}_{m s} \\
\mathbf{x}_{o}
\end{array}\right] \\
\text { and } \mathbf{x}_{A}=\left[\mathbf{x}_{o}\right],
\end{gathered}
$$

where $\mathbf{x}_{P}, \mathbf{x}_{F}$, and $\mathbf{x}_{U}$ are sets of phenotypic records for protein yield, cow fertility, and udder health, respectively, and $\mathbf{x}_{A}$ represents the additional fertility and udder health traits recorded in the nucleus herd; $\mathbf{x}_{s}$, $\mathbf{x}_{m s}$, and $\mathbf{x}_{o}$ describe 3 information sources for each trait group. The different scenarios were designed by varying the bull dam information in $\mathbf{x}_{o}$ vector, as shown in Table 1. 
Table 1. Scenarios included in the simulation study, abbreviations, and available information on bull dams

\begin{tabular}{ll}
\hline Scenario & Information known on bull dam \\
\hline Ped & Only pedigree index, based on traits recorded in the field \\
P & Protein yield \\
PF & Protein and fertility \\
PU & Protein and udder health \\
PFU & Protein, fertility, and udder health \\
PFUAd & Protein, fertility, udder health, and additional records on fertility and udder health \\
PFURes & Restricted index, based on the same information as in scenario PFU \\
PFUAdRes & Restricted index, based on same information as in scenario PFUAd \\
\hline
\end{tabular}

In all, 8 contrasting scenarios with varying amounts of known phenotypic information for the bull dams were simulated (Table 1). The Ped scenario was based on information from sire and grandsire progeny groups and included all of the field-recorded traits shown in Table 2. The information from these progeny groups was held constant in all scenarios, whereas the amount of information on the individual itself varied between scenarios P, PF, PU, PFU, and PFUAd. Scenario P was based only on protein yield, and PF and PU were based on protein yield and fertility, and protein yield and udder health, respectively. Scenario PFU combined these 3 types of traits. In PFUAd, additional records from the nucleus herd were added to investigate changes in the correlated response in breeding goal traits.
In the Nordic Cattle Genetic Evaluation (NAV), the following goal traits are included: milk production, beef production, calving traits, female fertility, mastitis, other diseases, longevity, and conformation traits (Pedersen et al., 2008). In the present study, the number of traits was reduced to simplify the simulation. The traits included were treated as representatives of 3 types of traits: milk production, cow fertility, and udder health. The field-recorded and nucleus-recorded traits used in the simulation are given in Table 2. They are numbered 0,1 , and 2 for heifers, first-, and secondlactation records, respectively. The field-recorded traits and the goal traits were pregnant at first insemination (PFI 0, PFI 1, PFI 2), interval between calving and first insemination (CFI 1, CFI 2), reproductive

Table 2. Simulated traits, heritabilities $\left(\mathrm{h}^{2}\right)$, genetic standard deviations $\left(\sigma_{\mathrm{A}}\right)$, and economic weights $(v$, $€$ per trait unit) for breeding goal traits

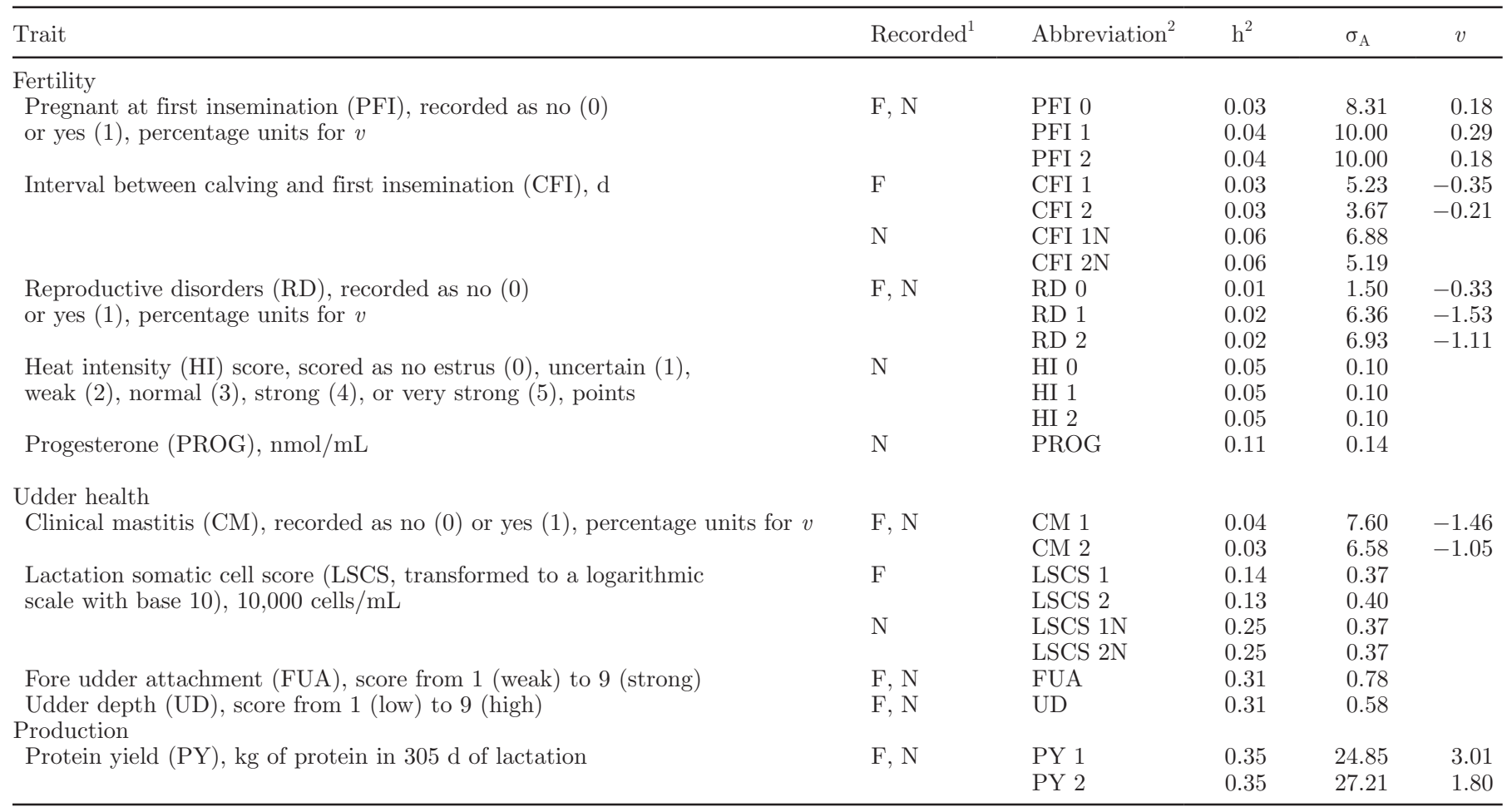

${ }^{1}$ Trait recorded in field $(\mathrm{F})$ or nucleus herd $(\mathrm{N})$.

${ }^{2}$ Trait recorded in heifers (0), in first lactation (1), or in second lactation (2). 
disorders (RD 0, RD 1, RD 2), and clinical mastitis (CM 1, CM 2). In addition to breeding goal traits, lactation SCS (LSCS 1, LSCS 2) was also recorded in the field.

In addition to the field-recorded traits, some additional recordings were assumed to have been made in the nucleus herd. Heat intensity score measures the cow's ability to show estrus and grades its strength (Roxström, 2001). Progesterone analysis of milk samples can be used to study postpartum ovarian activity in the dairy cow (Petersson, 2007). The trait CFI recorded in the nucleus was included in the simulation with higher heritability than in the field (0.06 vs. 0.03 ). In the nucleus herd, both CM and LSCS were recorded in 2 lactations; LSCS was assumed to have higher heritability in the nucleus herd (0.25 vs. 0.14 ), because it was recorded twice a month instead of once a month, as happens in the ordinary milk recording system.

The breeding goal $H$ was kept the same in all scenarios and was defined as follows:

$$
H=\mathbf{v}^{\prime} \mathbf{g}=\left[\begin{array}{lll}
\mathbf{v}_{P}^{\prime} & \mathbf{v}_{F}^{\prime} & \mathbf{v}_{U}^{\prime}
\end{array}\right]\left[\begin{array}{l}
\mathbf{g}_{P} \\
\mathbf{g}_{F} \\
\mathbf{g}_{U}
\end{array}\right],
$$

where $\mathbf{v}$ is a vector of economic weights for protein yield $\left(\mathbf{v}_{P}\right)$, fertility $\left(\mathbf{v}_{F}\right)$, and udder health traits $\left(\mathbf{v}_{U}\right)$, and $\mathbf{g}$ is a vector of genetic values for the corresponding traits. The traits in the breeding goal were ascribed economic weight, as shown in Table 2. They are based on economic weights used in NAV (Pedersen et al., 2008). Some adaptations of the NAV weights were introduced. First, in NAV, the economic weights are divided between lactations with the proportions $0.5,0.3$, and 0.2 for the first, second, and third lactations, respectively (K. Johansson, Swedish Dairy Association, Uppsala, Sweden, personal communication). In this study, only information from the first 2 lactations was used for PY and CFI, and therefore the economic weight for these traits was divided by the proportions 0.625 and 0.375 . Second, the economic weight for $\mathrm{RD}$ is divided into early and late reproductive disorders for cows in NAV. In this study, reproductive disorders in heifers were also included as a breeding goal trait. Some of the economic weight of late reproductive disorders was put on heifers, because early reproductive disorders (retained placenta) are not relevant for heifers. Third, the economic weight for PFI was calculated from the economic weight for number of inseminations used in NAV ( $€ 10.14$ per trait unit for heifers and €27.24 per trait unit for cows). The economic weight for cows was then divided with proportions 0.625 and 0.375 between 2 lactations.
For each scenario, phenotypic information on different traits was combined into an index $I$ for selection of bull dams (Hazel, 1943) as follows:

$$
I=b^{\prime} \mathbf{x}=\left[\begin{array}{llll}
b_{P} & b_{F} & b_{U} & b_{A}
\end{array}\right]\left[\begin{array}{l}
\mathbf{x}_{P} \\
\mathbf{x}_{F} \\
\mathbf{x}_{U} \\
\mathbf{x}_{A}
\end{array}\right],
$$

where $I$ is the selection index and $b_{P}, b_{F}, b_{U}$, and $b_{A}$ are the selection index weights.

The $b$-values are calculated as $b=\mathbf{P}^{-1} \mathbf{G v}$, where $\mathbf{P}$ is a square matrix of variances and covariances among the phenotypic measures and $\mathbf{G}$ a matrix of additive genetic covariances between the index traits and the breeding goal traits.

The accuracy of the index $\left(r_{H I}\right)$ was calculated as follows:

$$
r_{H I}=\frac{b^{\prime} \mathbf{G v}}{\sqrt{b^{\prime} \mathbf{P} b \mathbf{v}^{\prime} \mathbf{C v}}},
$$

where $\mathbf{C}$ is a matrix containing the additive genetic variances and covariances among the breeding goal traits. The genetic response per generation in different traits $\left(S_{g}\right)$ was calculated as follows:

$$
S_{g}=i \frac{b^{\prime} \mathbf{G}}{\sqrt{b^{\prime} \mathbf{P} b}}
$$

where $i$ is selection intensity, which was set to 1 . Thus, the genetic response in this study expresses solely the contribution of bull dam selection to total genetic response. The genetic response in the bull dam path for each trait was expressed in genetic standard deviation units.

The total genetic response per generation $\left(S_{H}\right)$ in monetary units was calculated with the general equation for one round of selection considering only bull dams:

$$
S_{H}=i \frac{b^{\prime} \mathbf{G v}}{\sqrt{b^{\prime} \mathbf{P} b}} .
$$

\section{Genetic and Phenotypic Parameters}

Assumed heritabilities and phenotypic standard deviations for all traits (Table 2) and genetic and phenotypic correlations between traits (Tables 3 and 4) were average values based on results from studies of relevant 
Table 3. Genetic (above the diagonal) and phenotypic (below the diagonal) correlations between field-recorded traits ${ }^{1}$ used in different scenarios

\begin{tabular}{|c|c|c|c|c|c|c|c|c|c|c|c|c|c|c|c|c|}
\hline & PFI 0 & PFI 1 & PFI 2 & CFI 1 & CFI 2 & RD 0 & RD 1 & RD 2 & CM 1 & CM 2 & LSCS 1 & LSCS 2 & FUA & UD & PY 1 & PY 2 \\
\hline PFI 1 & 0.04 & & 0.72 & -0.14 & 0 & 0 & -0.25 & -0.03 & 0.13 & 0.03 & -0.09 & -0.02 & 0.09 & 0 & -0.33 & -0.30 \\
\hline PFI 2 & 0.02 & 0.10 & & 0 & -0.15 & 0 & 0 & -0.26 & 0.03 & 0.14 & -0.01 & -0.09 & 0.09 & 0 & -0.30 & -0.33 \\
\hline CFI 2 & 0 & 0 & -0.12 & 0.09 & & 0 & 0 & 0.40 & 0.22 & 0.29 & 0.02 & 0.06 & 0.13 & 0.04 & 0.33 & 0.35 \\
\hline RD 0 & 0 & 0 & 0 & 0 & 0 & & 0.32 & 0.32 & 0 & 0 & 0 & 0 & 0 & 0 & 0 & 0 \\
\hline RD 1 & 0 & -0.30 & 0 & 0.10 & 0 & 0.01 & & 0.58 & 0.01 & -0.01 & 0.02 & -0.02 & 0 & 0 & 0.14 & 0.13 \\
\hline LSCS 1 & 0 & 0 & 0 & 0 & 0 & 0 & 0 & 0 & 0.50 & 0.30 & & 0.82 & -0.24 & -0.30 & 0.24 & 0.15 \\
\hline LSCS 2 & 0 & 0 & 0 & 0 & 0 & 0 & 0 & 0 & 0.30 & 0.50 & 0.36 & & -0.24 & -0.30 & 0.15 & 0.24 \\
\hline FUA & 0 & 0.01 & 0.01 & 0.03 & 0.01 & 0 & 0 & 0 & -0.06 & -0.06 & -0.07 & -0.07 & & 0.66 & -0.23 & -0.23 \\
\hline UD & 0 & 0 & 0 & 0.01 & 0.01 & 0 & 0 & 0 & 0 & 0 & -0.09 & -0.09 & 0.30 & & -0.25 & -0.25 \\
\hline PY 1 & 0 & -0.10 & -0.09 & 0.11 & 0.09 & 0 & 0.07 & 0.06 & -0.06 & -0.01 & -0.09 & -0.03 & -0.07 & -0.10 & & 0.84 \\
\hline PY 2 & 0 & -0.09 & -0.10 & 0.09 & 0.11 & 0 & 0.06 & 0.07 & -0.01 & -0.03 & -0.03 & -0.06 & -0.07 & -0.10 & 0.50 & \\
\hline
\end{tabular}

${ }^{1}$ For abbreviations, see Table 2.

field records (Mäntysaari and van Vleck, 1989; Lund et al., 1994; Pösö and Mäntysaari, 1996; Sørensen et al., 2000; Roxström, 2001; Veerkamp et al., 2001; Hansen et al., 2002; Carlén et al., 2004; Buch and Norberg, 2008; Holtsmark et al., 2008). Correlations between progesterone in milk (first lactation) and fertility traits were estimated from a dataset used by Royal et al. (2002). The genetic correlation matrix was converted into a positive definite matrix by applying a bending procedure before it was used in the simulations. The matrix was first reduced to canonical form. All negative roots were set to a very small positive value (0.00001). Then, the matrix was recalculated. The resulting matrix was pre- and post-multiplied with the inverse of the square root of its diagonal to hold the heritability unchanged. Changes in genetic correlations due to bending were small, ranging between 0.01 and 0.07 . The genetic correlations after bending and phenotypic correlations (not bended) are presented in Table 3. Table 4 displays genetic correlations between nucleus-recorded traits and field-recorded traits after bending.

To investigate the importance of selected correlations between protein yield and the low heritability traits a sensitivity study was undertaken. The genetic correlations between protein yield and traits within each of the functional trait groups (fertility and udder health traits) were either increased or decreased by $30 \%$.

\section{Derivation of the Bull Dam Total Weights}

The first 6 scenarios all resulted in an undesired genetic response in functional traits. Therefore, the restricted index theory, as presented by Cunningham (1969) and Brascamp (1984), was applied to derive the bull dam total weights to set the genetic response to zero. A dummy variable was added to the index for each restriction. A corresponding row and column were added to the $\mathbf{P}$ matrix, and a row of zeros was added to the $\mathbf{G}$ matrix. In this study, the restricted index was used to obtain zero genetic change in 4 fertility traits (PFI 1, PFI 2, CFI 1, and CFI 2) and 2 udder health traits (CM 1, CM2). The last 2 scenarios in Table 1, PFURes and PFUAdRes, used a restricted index, without and with additional records from the nucleus herd, respectively.

\section{RESULTS AND DISCUSSION}

The genetic response gained from bull dam selection in each scenario is presented in Table 5. Information on both lactations is included. The first scenario, Ped, corresponds to a situation in which heifers that arrive at the nucleus and are flushed for embryos are selected as bull dams. In this scenario, the genetic response in genetic standard deviation units per generation was -0.17 in PFI 1 and PFI 2, 0.17 in CFI 1, 0.16 in CFI 2, 0.11 in $\mathrm{CM} \mathrm{1,} \mathrm{and} 0.10$ in $\mathrm{CM} 2$. The genetic response in protein yield was 0.52 (PY 1) and 0.50 (PY 2 ) genetic standard deviation units per generation. The unfavorable genetic response in low heritability traits in this scenario was expected, given that no additional information besides pedigree index was used for bull dam candidates at the time of selection. The accuracy of the index was low (0.53), but it is comparable to accuracies known from the selection of young bulls.

Table 5 also gives the total response in euros, which reveals exactly how much bull dam selection contributes to the response in breeding goal. Selecting a heifer as a bull dam would give $€ 60.34$ in total response.

The second scenario, $\mathrm{P}$, describes the situation in which the selection of bull dams is based on milk production records only. In this case, the genetic response 
Table 4. Genetic correlations between nucleus-recorded traits and field-recorded traits used in different scenarios ${ }^{1}$

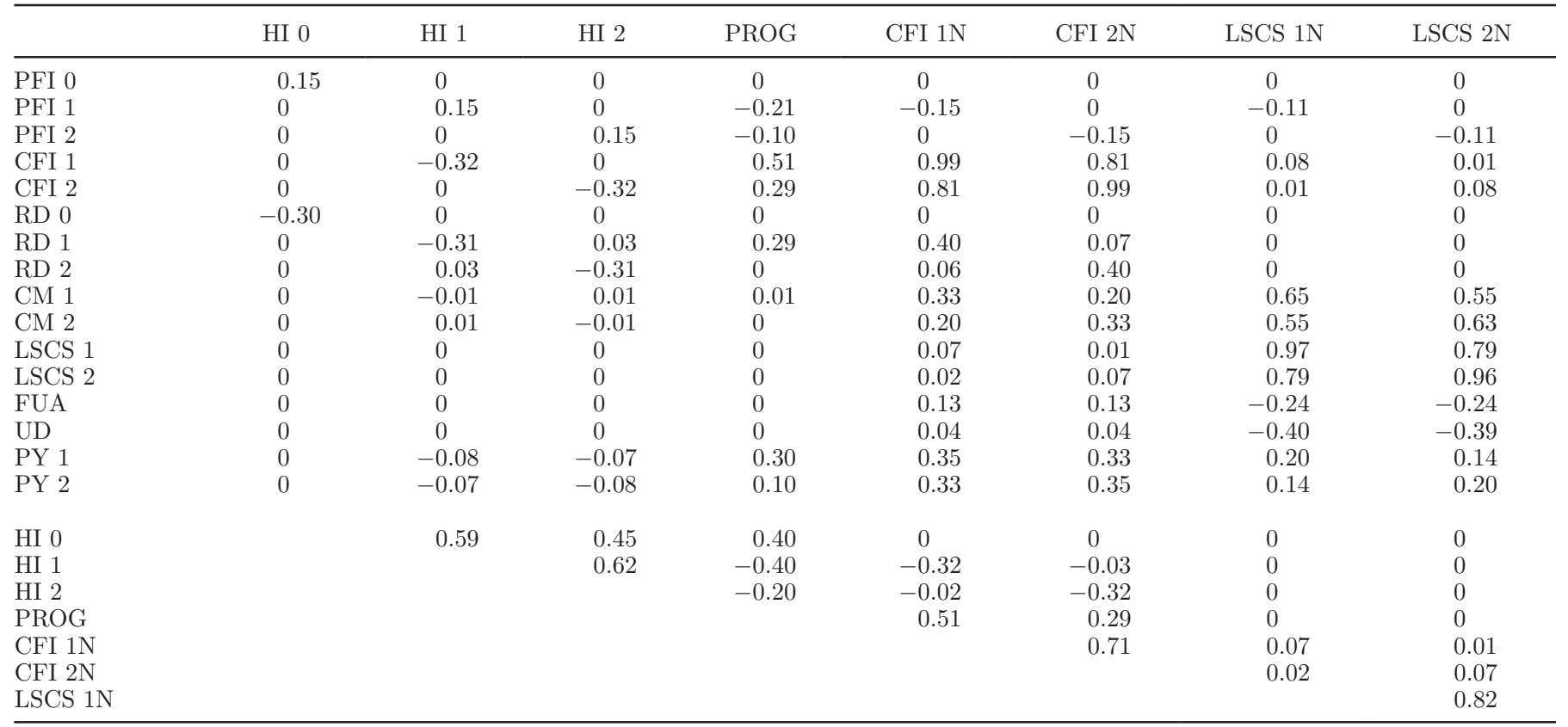

${ }^{1}$ For abbreviations, see Table 2 .

in protein yield became 0.70 in PY 1 and 0.69 in PY 2 . The accuracy of selection was 0.72 . The total response increased from $€ 60.34$ to $€ 81.94$ compared with scenario Ped. However, in scenario P, functional traits were not recorded. In fact, of course, scenario P is irrelevant in a breeding program aiming at a sustainable production (Nielsen et al., 2005), because single-minded selection for high production leads to undesirable side effects (Rauw et al., 1998). It was included only to show how much the functional traits are affected by narrow selection for protein yield. As compared with the first scenario (Ped), the genetic response for low heritability traits became more unfavorable. The correlated genetic response in functional traits, measured in genetic standard deviation units per generation, in scenario $\mathrm{P}$, was
-0.12 in PFI $0,-0.24$ in PFI 1 and 2, 0.24 in CFI 1 and 2, and 0.16 in CM 1 and 2.

When comparing scenarios where either fertility or udder health was recorded on the potential bull dams, the increase in genetic response in PY 1 and PY 2 in scenario PU was slightly higher than it was in scenario $\mathrm{PF}$. This was because of differences in the genetic parameters and economic weights of fertility and udder health traits. The genetic response in traits PFI 0,1 , and 2 was even more unfavorable in scenario PF than it was in scenario P. Not recording the udder health traits (scenarios $\mathrm{P}$ and $\mathrm{PF}$ ) resulted in a genetic response of 0.16 in $\mathrm{CM} 1$ and 2, respectively, whereas in scenario PU the response became 0.22 in CM 1 and 0.21 in $\mathrm{CM}$ 2. Reproductive disorders in heifers (RD 0) was the

Table 5. Genetic response per generation (genetic standard deviation units) in field-recorded traits, accuracy of the index $\left(r_{H I}\right)$, and total response $\left(S_{H}^{1}\right)$ in euros depending on the amount of information used for bull dams ${ }^{2}$

\begin{tabular}{|c|c|c|c|c|c|c|c|c|c|c|c|c|c|c|}
\hline Scenario & \multicolumn{12}{|c|}{ Trait } & $r_{H I}$ & $S_{H}$ \\
\hline Ped & -0.09 & -0.17 & -0.17 & 0.17 & 0.16 & -0.01 & 0.05 & 0.04 & 0.11 & 0.10 & 0.52 & 0.50 & 0.53 & 60.34 \\
\hline $\mathrm{PF}$ & -0.13 & -0.25 & -0.25 & 0.24 & 0.23 & -0.01 & 0.08 & 0.07 & 0.16 & 0.16 & 0.71 & 0.70 & 0.72 & 82.21 \\
\hline $\mathrm{PU}$ & -0.12 & -0.24 & -0.24 & 0.24 & 0.24 & -0.01 & 0.08 & 0.08 & 0.22 & 0.21 & 0.72 & 0.71 & 0.73 & 82.90 \\
\hline PFU & -0.13 & -0.25 & -0.25 & 0.24 & 0.24 & -0.01 & 0.08 & 0.07 & 0.18 & 0.18 & 0.72 & 0.70 & 0.73 & 82.81 \\
\hline PFUAdRes & 0.07 & 0.00 & 0.00 & 0.00 & 0.00 & -0.03 & -0.01 & -0.01 & 0.00 & 0.00 & 0.48 & 0.48 & 0.54 & 60.77 \\
\hline
\end{tabular}

${ }^{1} S_{H}$ with economic weights from Table 2 .

${ }^{2}$ For abbreviations, see Tables 1 and 2 . 
only functional trait to show a desired genetic response through all of the scenarios, but the genetic response in RD 1 and 2 was unfavorable and varied from 0.04 to 0.08 in different scenarios. In scenario PFU, the bull dam candidates had records from 2 lactations on traits that are routinely recorded in the Swedish milk recording scheme. Normally, in the Swedish nucleus herd, the bull dams would be flushed for embryos to produce bull calves after completing their first lactation and part of the second lactation, as in this scenario. According to the results from scenario PFU, selection of bull dams in the nucleus herd on the basis of known records and current economic weights did not improve the genetic response in functional traits. These results represent a departure from what had been hypothesized at the outset of this study.

The PFUAd scenario included some additional records taken in the nucleus herd to gain more information on low heritability traits and to make the selection more accurate. The total response in euros was highest in scenario PFUAd. However, the correlated response in fertility and udder health traits did not improve. Additional traits such as progesterone, and CFI recorded in the nucleus with doubled heritability, clearly had an unfavorable effect on the genetic response of CFI in the field. In addition, the genetic response in CM became more unfavorable when SCS recorded in the nucleus herd with higher heritability (LSCS N) was included. The genetic response in protein yield became 0.73 and 0.72 genetic standard deviation units per generation for PY 1 and 2, and the accuracy of the index was 0.74 in this scenario.

To find an explanation of the undesired genetic response in functional traits in this simulation study, the correlation matrix was sensitivity tested. Raising and lowering the correlations by $30 \%$ failed to alter the results for functional traits. The genetic response in these traits remained unfavorable. Thus, it became apparent that the economic weights from the current NAV evaluation used in index equations were too low to prevent functional traits from deteriorating, and that this, in combination with the heritability of protein yield, was causing the unfavorable genetic response. In this study, the genetic responses for different traits were investigated using an index containing all traits simultaneously in a multi-trait model. This full multitrait model is theoretically more accurate, but it is not used in the current Nordic cattle genetic evaluation. The NAV uses separate evaluations for each trait group today, with gained sub-indexes then being weighed into a Nordic Total Merit Index (NTM). When trait groups are evaluated separately, correlations between traits in different groups will not be expected to affect the outcome in the way they do in the current study. For example, in our simulation, the inclusion of SCC supported the selection for protein yield, whereas the intention was for it to support selection against clinical mastitis. In fact, when considering both production and functional traits, even more selection pressure is put on the production of the individual cow. The increase in genetic response in protein yield when traits with low heritability and low or no economic weight were added to the index is in agreement with studies conducted by Smith (1983). He found that the trait with highest heritability and economic weight would dominate the index.

According to Hazel (1943), the economic weights should be calculated from the change in profit of the production system by a unit of genetic improvement in a given trait. These weights might, however, result in unfavorable responses in traits important for animal welfare or other aspects of sustainable milk production (Rauw et al., 1998). In our simulation study, fertility and udder health decreased. Over the long term, such trends would have a negative effect on animal welfare, and thus limit profits from milk production, as discussed by Olesen et al. (2000). New bull dam total weights for PFI 1 and PFI 2, for field-recorded CFI 1 and CFI 2, and for CM 1 and CM 2, were derived using a restriction index to ensure that no genetic deterioration in these traits took place. The resulting bull dam total weights for those traits, obtained from the PFURes and PFUAdRes scenarios, were considerably higher than the corresponding weights used in NAV (Table $6)$. When summarized over lactations, the economic weights adapted from NAV (expressed in euros per trait unit) were $€ 4.81$ for PY, $€ 0.65$ for PFI, $-€ 0.56$ for CFI, $-€ 2.97$ for $\mathrm{RD}$, and $-€ 2.51$ for CM. In the PFURes scenario, the new bull dam total weights became $€ 7.84$ for PFI, $-€ 12.63$ for CFI, and $-€ 7.89$ for CM; that is, 12 to 23 times higher for fertility and 3 times higher for mastitis than the NAV weights currently used. In the PFUAdRes scenario, the corresponding bull dam total weights became $€ 7.57$ for PFI, $-€ 12.26$ for CFI, and $-€ 7.24$ for CM. These weights are summarized over lactations. The total weights per lactation are shown in Table 6. The resulting weights in the PFUAdRes scenario were slightly different from those in PFURes, because more traits were included in the PFUAdRes index. The correlated genetic response in traits PFI 0, $\mathrm{RD} 0, \mathrm{RD} 1$, and RD 2 turned in the desired direction after the bull dam total weights for the other functional traits had been changed. Therefore, no restriction on these traits was needed. Larger total weights on functional traits caused a substantial decrease in response in PY 1 and 2, which decreased from 0.72 and 0.70 
Table 6. Current economic weights (€ per trait unit) used in the Nordic Cattle Genetic Evaluation and new bull dam total weights from restricted index for traits in breeding goal ${ }^{1}$

\begin{tabular}{lcrrr}
\hline & & & \multicolumn{2}{c}{ Scenario } \\
\cline { 4 - 5 } Trait & Restricted $^{2}$ & $\begin{array}{c}\text { Current } \\
\text { weights }\end{array}$ & PFURes & PFUAdRes \\
\hline PFI 0, percentage units & & 0.18 & 0.18 & 0.18 \\
PFI 1, percentage units & $\mathrm{X}$ & 0.29 & 3.73 & 3.95 \\
PFI 2, percentage units & $\mathrm{X}$ & 0.18 & 3.93 & 3.44 \\
CFI 1, d & $\mathrm{X}$ & -0.35 & -7.36 & -4.73 \\
CFI 2, d & $\mathrm{X}$ & -0.21 & -5.27 & -7.53 \\
RD 0, percentage units & & -0.33 & -0.33 & -0.33 \\
RD 1, percentage units & & -1.53 & -1.53 & -1.53 \\
RD 2, percentage units & $\mathrm{X}$ & -1.11 & -1.11 & -1.11 \\
CM 1, percentage units & $\mathrm{X}$ & -1.46 & -4.10 & -4.39 \\
CM 2, percentage units & & 3.05 & -3.79 & -2.85 \\
PY 1, kg (305 d) & & 1.80 & 3.01 & 3.01 \\
PY 2, kg (305 d) & & & 1.80 & 1.80 \\
\hline
\end{tabular}

${ }^{1}$ For abbreviations, see Tables 1 and 2.

${ }^{2}$ Restriction was applied to this trait.

(scenario PFU) to 0.48 and 0.48 genetic standard deviation units (Table 5), respectively. However, in cattle breeding today, the trend is toward sustainable breeding programs with an emphasis on functional traits (Olesen et al., 2000; Nielsen et al., 2005). Besides conventional economic weights derived from profit equations, sustainable breeding goals also include nonmarket values that account for animal welfare and ethical aspects (Olesen et al., 2000). In our study, the new bull dam weights consist of both economic and nonmarket values, with these jointly resulting in total economic weight. For example, the new bull dam total weight for PFI 1 was 3.73 in scenario PFURes (Table 6), where 0.29 was the economic weight and 3.44 was the nonmarket value. Nielsen et al. (2005) used restricted indexes to calculate nonmarket values for conception rate, mastitis resistance, and stillbirth. Acceptance of a degree of reduction in milk production resulted in nonmarket values that were up to 3 times higher than the market economic values when considering the effects of all selection paths. Considerable differences exist between economic weights in different selection schemes. According to the breeding organization Geno, the main part of the relative weight is given to health, fertility, and other functional traits in the Norwegian breeding goal, leaving only $28 \%$ of the relative weight to milk production (Geno, 2010).

The simulation results showed that scenario PFUAd was most profitable. The scenarios that included only field-recorded traits all resulted in almost the same total genetic response.

Recent implementation of genomic selection in dairy cattle breeding plans is changing the role of nucleus herds in bull dam selection. Genomic selection allows the EBV of young animals to be predicted more accurately than they can be when they are based on parent averages. Bull calves are genotyped at an early age, and the selection decisions are made based on genomically enhanced breeding values (Hayes et al., 2009). Schaeffer (2006) has argued that genomic selection could be a very useful tool also on the maternal side. Genotyping potential bull dams and selecting them based on their genomically enhanced breeding values gave higher genetic gain as a result of the considerable increase in accuracy. The individual testing of bull dams in a nucleus herd (as happens today), together with the use of genomic selection in combination with the MOET nucleus scheme, may take selection on the maternal side to a higher level, provided that records can be obtained for important traits that cannot easily be obtained in regular recording schemes. For example, developed nucleus herds and contracted conventional herds could be used as reference herds and contribute important records of traits such as leg and hoof diseases, feed conversion, and milk composition at the micro level in future breeding schemes.

\section{CONCLUSIONS}

Bull dams could be selected for functional traits in a nucleus herd, but such selection will require very high total (economic and nonmarket) weights for functional traits if undesired genetic gain in these traits in the bull dam selection path is to be avoided. The introduction of new indicator traits, and of more advanced recording methods for functional traits, does not halt the deterioration of functional traits in multiple trait settings when the main constituent of economic weight is still 
placed on protein yield and the functional traits are also recorded in the field and used for progeny testing of AI bulls.

\section{ACKNOWLEDGMENTS}

The authors are grateful for financial support from the Swedish Farmers' Foundation for Agricultural Research (SLF, Stockholm, Sweden). We also thank Hans Stålhammar, of Viking Genetics (Skara, Sweden), for valuable advice on the choice of scenarios for nucleus herd selection of bull dams.

\section{REFERENCES}

Bovenhuis, H., E. Niebel, and D. Fewson. 1989. Implications of selection for secondary traits on MOET-nucleus cattle breeding programs for dairy and dual-purpose breeds. Livest. Prod. Sci. $22: 237-254$.

Brascamp, E. W. 1984. Selection indices with constraints. Anim Breed. Abstr. 52:645-654.

Buch, L. H., and E. Norberg. 2008. Genetic analysis of protein yield, udder health, and female fertility in first-parity Danish Holstein cows. Acta Agric. Scand. A 58:5-9.

Carlén, E., E. Strandberg, and A. Roth. 2004. Genetic parameters for clinical mastitis, somatic cell score and production in the first three lactations of Swedish Holstein cows. J. Dairy Sci. 87:3062-3070.

Cunningham, E. P. 1969. Animal Breeding Theory. Internordic licenciat course in quantitative genetics. Inst. Anim. Genet. Breeding, Agric. College Norway. Landbruksbokhandelen/Universitetsforlaget Vollebekk, Oslo, Norway.

GENO. 2010. Norwegian Red Characteristics. Breeding Objective. Accessed Nov. 26, 2010. http://www.genoglobal.no/ Home/Norwegian-Red-Characteristics/Norwegian-Red/.

Hansen, M., M. S. Lund, M. K. Sørensen, and L. G. Christensen. 2002. Genetic parameters of dairy character, protein yield, clinical mastitis, and other diseases in the Danish Holstein cattle. J. Dairy Sci. 85:445-452.

Hayes, B. J., P. J. Bowman, A. J. Chamberlain, and M. E. Goddard. 2009. Invited review: Genomic selection in dairy cattle: Progress and challenges. J. Dairy Sci. 92:433-443.

Hazel, L. N. 1943. The genetic basis for constructing selection indices. Genetics 38:476-490.

Holtsmark, M., B. Heringstad, P. Madsen, and J. Ødegård. 2008. Genetic relationship between culling, milk production, fertility, and health traits in Norwegian Red cows. J. Dairy Sci. 91:40064012.

Juga, J., and A. Mäki-Tanila. 1987. Genetic change in a nucleus breeding dairy herd using embryo transfer. Acta Agric. Scand. A 37:511-519.

Lund, T., F. Miglior, J. C. M. Dekkers, and E. B. Burnside. 1994. Genetic relationship between clinical mastitis, somatic cell count and udder conformation in Danish Holsteins. Livest. Prod. Sci. $39: 243-251$.

Mäntysaari, E. A., and L. D. van Vleck. 1989. Estimation of genetic parameters for production and reproduction in Finnish Ayrshire cattle. J. Dairy Sci. 72:2375-2386.

Meuwissen, T. H. E. 1989. A deterministic model for the optimization of dairy cattle breeding based on BLUP breeding value estimates. Anim. Prod. 49:193-202.
Meuwissen, T. H. E., and J. A. Woolliams. 1993. Responses of multitrait selection in open nucleus schemes for dairy cattle breeding. Anim. Prod. 56:293-299.

Nielsen, H. M., L. G. Christensen, and A. F. Groen. 2005. Derivation of sustainable breeding goals for dairy cattle using selection index theory. J. Dairy Sci. 88:1882-1890.

Norberg, E. 2004. Electrical conductivity of milk as a phenotypic and genetic indicator of bovine mastitis. PhD Thesis. Dept. Animal Breeding and Genetics, Danish Inst. Agric. Sci. Res. Centre Foulum, Denmark.

Olesen, I., A. F. Groen, and B. Gjerde. 2000. Definition of animal breeding goals for sustainable production systems. J. Anim. Sci. $78: 570-582$.

Pedersen, J., M. K. Sørensen, M. Toivonen, J.-Å. Eriksson, and G. Pedersen Aamand. 2008. Report on economic basis for Nordic Total Merit Index. Report from Nordic Cattle Genetic Evaluation. Accessed Dec. 1, 2008. http://www.nordicebv.info/NR/rdonlyres/ B618C0E5-FF6F-4D31-8F86-B3CE4A140043/0/NAV_TMI_ report_lastversion_131108.pdf.

Petersson, K.-J. 2007. Milk progesterone as a tool to improve fertility in dairy cows. Doctoral thesis No. 2007:46. Faculty of Veterinary Med. and Animal Science, Swedish University of Agricultural Sciences, Uppsala.

Philipsson, J., G. Banos, and T. Arnason. 1994. Present and future uses of selection index methodology in dairy cattle. J. Dairy Sci. $77: 3252-3261$

Pösö, J., and E. A. Mäntysaari. 1996. Relationships between clinical mastitis, somatic cell score, and production for the first three lactations of Finnish Ayrshire. J. Dairy Sci. 79:1284-1291.

Rauw, W. M., E. Kanis, E. N. Noordhuizen-Stassen, and F. J. Grommers. 1998. Undesirable side effects of selection for high production efficiency in farm animals: A review. Livest. Prod. Sci. 56:15-33.

Roxström, A. 2001. Genetic aspects of fertility and longevity in dairy cattle. PhD Thesis. Agraria 276. Dept. Animal Breeding and Genetics, Swedish University of Agricultural Sciences, Uppsala.

Royal, M., A. P. F. Flint, and J. A. Woolliams, 2002. Genetic and phenotypic relationships among endocrine and traditional fertility traits and production traits in Holstein-Friesian dairy cows. J. Dairy Sci. 85:958-967.

Schaeffer, L. R. 2006. Strategy for applying genome-wide selection in dairy cattle. J. Anim. Breed. Genet. 123:218-223.

Smith, C. 1983. Effects of changes in economic weights on the efficiency of index selection. J. Anim. Sci. 56:1057-1064.

Sørensen, M. K., J. Jensen, and L. G. Christensen. 2000. Udder conformation and mastitis resistance in Danish first-lactation cows: Heritabilities, genetic and environmental correlations. Acta Agric. Scand. A Anim. Sci. 50:72-82.

Strandén, I., P. Korpiaho, M. Pakula, and E. A. Mäntysaari. 2001. Bull selection in MOET nucleus breeding schemes with limited testing capacity. Acta Agric. Scand. A Anim. Sci. 51:235-245.

Teepker, G., and C. Smith. 1990. Efficiency of MOET nucleus breeding schemes in selecting for traits with low heritability in dairy cattle. Anim. Prod. 50:213-219.

Uimari, P., and E. A. Mäntysaari. 1995. Relationship between bull dam herd characteristics and bias in estimated breeding value of bull. Agric. Sci. Finl. 4:463-472.

Veerkamp, R. F., E. P. C. Koenen, and G. De Jong. 2001. Genetic correlations among body condition score, yield, and fertility in first-parity cows estimated by random regression models. J. Dairy Sci. 84:2327-2335

Zwald, N. R., and K. A. Weigel. 2002. Examination of methods to correct for preferential treatment among AI bull dams. J. Dairy Sci. 85(Suppl. 1):32. (Abstr.) 